\section{Payments for Ecosystem Services in Japan: the Private Sector's Approach in the Rural Areas}

\section{Tomoyo Chiba ${ }^{a^{*}}$, Kazuo Matsushita ${ }^{\mathrm{b}}$}

${ }^{a}$ Kyoto University Graduate School of Global Environmental Studies, Yoshida-Honmachi, Sakyo-ku, Kyoto, 6o6-8501, Kyoto, Japan

${ }^{b}$ Professor Emeritus at Kyoto University

Received: April 1, 2013/ Accepted: September 25,2013

\begin{abstract}
In this article,the current statusof Payments for Ecosystem Services (PES)in rural areas by Japanese private companiesis clarified and their characteristics are discussed.A comparative analysis of three cases was undertaken, including two Japanese cases:(1) the buyer, a beverage company, pays indirectly to the sellers farmers/foresters through public institutions, and (2) the buyer, a semiconductor manufacturing company, pays to the sellers based upon direct negotiation; the third case (3), is a textbook example by French company Nestlé Waters. As a result of the analysis, some interesting characteristics were identified.Firstly, the paid-for conservation act is specified and quantitative evaluation is conducted inthe direct negotiationscenarios(2) and (3), whereas in the indirect payment case(1), the sellers were allowed to decide the details of the conservation activities and quantitative evaluation was not conducted with the same level of rigour. On the other hand, the standard of setting the rate of payment was different between thecases depending on the social background of the communitiesin which thePES is enforced. It was also found that all cases shared a common element, in that intermediaries playessentialroles to facilitate communication between the companies and the farmers/foresters.
\end{abstract}

Keywords:Payments for Ecosystem Services; Private Sector's Approach; Ecosystem Services in Rural Areas

* Corresponding Author

Tel.: +81-75-753-9167; Fax.: +81-75-753-9187;

E-mail: chiba.tomoyo.56m@st.kyoto-u.ac.p

\begin{tabular}{|c|c|c|}
\hline PES & : & Payments for Ecosystem Services \\
\hline CBD- & : & Convention onBiological \\
\hline $\mathrm{COP}$ & & Conference of Parties \\
\hline TEEB & : & $\begin{array}{l}\text { The Economics of Ecosystem Services and } \\
\text { Biodiversity }\end{array}$ \\
\hline WBCSD & : & $\begin{array}{l}\text { World Business Council for Sustainable } \\
\text { Development }\end{array}$ \\
\hline IUCN & : & $\begin{array}{l}\text { International Union for Conservation of } \\
\text { Nature }\end{array}$ \\
\hline ICDPs & : & $\begin{array}{l}\text { Integrated Conservation and Development } \\
\text { Projects }\end{array}$ \\
\hline SFM & : & Sustainable Forest Management \\
\hline
\end{tabular}

\section{Introduction}

Payments for Ecosystem Services (PES) are one environmental economic approach to conserve the natural environment that has been attracting attention. The core idea of PES is that the beneficiaries of ecosystem services give incentives for the conservation of these services to landowners or local actors who can provide them, by compensating them for the costs of environmental conservation and management.

Introducing PES as a political measure has been called for at the international level. At the Convention onBiological Diversity Conference of Parties 9 (CBD-COP9), a resolution was passed to seek out new and innovative financial mechanisms including PES (Decision IX/11). In the report "The Economics of Ecosystem Services and Biodiversity (TEEB)" which was announced at CBD-COP1o, a political proposal was made to decision makers on theimplementation ofPES schemes.

In recent years, the application of PES schemes has alsobeen considered in Japan. The importance of diffusing and implementing PES schemesare specified in the 'National Biodiversity Strategy of Japan 2012-2020' which was developed in 2012.

In this paper,we focus on the application of PES in rural areas in Japan where it can possibly bean effective tool for ecosystem service conservation. Ecosystem services in rural areas are various, and cover a wide range at the local, regional, and public levels. Using agricultural land as an example, at the local level, the major benefit is gained from the usage value for agricultural production, recreationand so on, whereas at the regional and global level most of the benefit is gained from non-use value such as biodiversity, landscape and others. However, in most cases, the expense of ecosystem services management is borneby local people while beneficiaries of those services in urban areas don't pay for them.Ecosystem services in rural areas in Japan have been maintained to the current extent due tolocal people who invest labor in managing the agricultural land and 
forestto maximize the profitsgainedfrom agricultural and forestry products.Since these investments are always made with an expectation of earning incomefrom those products, if the investment does not pay off, the local people lose incentive for resource management andcease their production activities. As a result of the reduction inhuman interactions, both the biodiversity and ecosystem services have deteriorated. Abandonment and underuse of farmlands and artificial forests has become one of the threats to biodiversity and ecosystem services in rural areas in Japan [1][2].

The cost of conservation of ecosystem services in rural areas has been dependentin no small part on the national treasury for income. In fact, many municipalities in rural areas are dependent on the national treasury for all aspects of finance. Various subsidies for agriculture and forestry such asthe Direct Payment System for Hilly and Mountainous Areas and Measures to Conserve and Improve Land, Water, and Environment as well as public projects regarding rural environmental improvement have contributed to the management of ecosystem services. However, due to the continuous decline in population and aging demographics, tax income has stagnated and tax allocation to local governments has been on the decrease, along with an increasing demand for revenue efficiency. In addition, the Proper Burden Principle tends to be emphasizedunder the process of reform of local finance systems. Under such a situation, it is necessary to diversify and enhance the mechanisms of funding to conserve ecosystem services in rural areas.It is considered that there is a possibility that the idea of PES can achieve the income transfer from the beneficiaries of ecosystem services in urban areas to the providers of those services in rural areas (thosewho are engaged in agriculture and forestry). If we could make good use of the PES idea, a mechanism could be established in which external beneficiaries who enjoy ecosystem services from rural areas pay appropriate compensation and by using this payment,local people receive a fair reward fortheir management of farmland and forests.

In this paperthe authors focus on the voluntary approachesofthe private sector, especially businesses, as a means of promoting PES for conserving ecosystem services in rural areas in the future. Most private companies use ecosystem services both directly and indirectly, and there are many industries that cannot exist without a stable supply of ecosystem services.Considering that the financial situation of the public sector, including the central and the local governments (who have so far played a role in investing in conservation) is deteriorating, it isimportant to discuss mechanisms or institutions to make the private sectortake on the burden or appropriate costs of conservation of ecosystem services they use, based on the Beneficiary Pays Principle.According to the report of World Business Council for Sustainable Development (WBCSD) and the International Union for Conservation of Nature (IUCN), there have been some successful cases of PES schemes led by private companies. It has been mentioned that PES can be an effective method in order to get the private sector involved in ecosystem services conservation [3].

However, most of the time, PES is introduced as examples of agriculture and forestry promotion measures by the public sector, and there has been little discussion on the private sector's approach to PES.In this paperthemain objective is to reveal the characteristics of PES schemes entered into bybusinesses in Japan through investigating two cases and comparing them with one of the most typical cases of a PES scheme by private sectorfrom overseas.

This article consists of two parts. Firstly,we'll try to set a clear definition of the term PES in this article as a new idea of conservation. Wunder [4]mentioned that the literature so far has not formally defined PES, which has confused the discussion in this area. In response, they setfive criteria to describe the PESprinciple (detailed later)[4]. However there has been some controversy and the definition of PES has yet to be agreed on, despite atracting widespread interest as an innovative tool for financing conservation.Therefore it is necessary to define what PES means in this article before taking up the main subject. The summary of the results of the case study investigationsare thendescribed and their characteristics discussed.

\section{Definition of PES}

\subsection{Ambiguity of the term PES}

As has been mentioned already, while the idea of PES has been rapidly gaining global attention, itsdefinition has not yet been established [4][5]. As a result, the term PES has been used with various meanings with the tendency that the definition is becoming ambiguous, as has been observed in many cases regardless of business practice or research level. In recent years, there has been a tendency for the term to be used as a generic term for market-based biodiversity conservation mechanisms.

Therefore, the detail of how the idea of PES originated will be briefly described in section 2.2 by referring to previous works. The definition of PES as applied in this article will then be stated, clarifying the basis for extracting learnings from the cases analyzed in section 2.3.

\subsection{The origin of PES}

Protection of the natural environmentfromthe latter half of $19^{\text {th }}$ century was mostly dependent on setting asideprotected areas such asnational parks and regulating land use in those areas. However, these approaches were revealed to be not alwayseffective, especially in developing countries. The local residents sometimes took on uncooperative attitudesto the strict regulations brought about from outside. And there were some cases in which the indigenous people were 'driven out' from the legally constituted territories, whichnegatively impacted on them both culturally and socioeconomically [6]. The lack of 
appropriate governance systemsin the area also prevented this method of nature protection from being ultimately effective [7].

In this situation, participatory conservation such as Integrated Conservation and Development Projects (ICDPs) and Sustainable Forest Management (SFM) have emerged as supplementary approaches to direct regulation ofprotected areas[8][9].ICDP is an approach that aspires to combine social development with conservation, aiming to achieve both better living and welfare of local residents and conservation of natural resources at the same time [10]. ICDPs promoted the local communities'participation in the process of implementing the conservationprojects andtried to deal withtheir social and economic requirements, benefitting themby transferring money from eco-tourism, stimulating environmental friendly agricultural production and so on. However, such indirect means as tourism and creating a market for agricultural products did not produce much economic benefit for the local population and didn't work for effective conservation[11]. This situation generated interest in the more direct methods already implemented in some developed countries in Europe and the U.S.[9]. The basic idea of thismethod is to enable one who desires conservation of nature to buy the conservation activities directly from the one who undertakes the conduct of the activities at a negotiated price. The conservation schemes based on this idea have been spreading gradually in developing countries especially sincethe Rio summit in 1992. They achieved an effect especially in areasthatcouldn't be coveredby setting protected areasordirect regulation only [9]. This approach of buying conservation activitiesdirectly has been given various names such as 'performancepayments' [12], 'Conservation Concessions' [12], 'Compensation and Rewards for Environmental Services' [9],'Compensation for Environmental Services' [13], and others. In recent years in most literature or reports it is referred as 'payment(s) for environmental service(s)' or 'payment(s) for ecosystem service(s)', the origin of PES.

\subsection{Definition of PES}

PES was conceptualized as a conservation approachbased upon direct transaction between the users of ecosystem services and the providers who are the owners, users or managers of the land where the ecosystem services are provided [14]. Based on this concept Wunderpresentedfive criteria of PES [4]:

I.a voluntary transaction where

II.a well-defined ecosystem service (or a land-use likely to secure that service)

III.is being 'bought' by a (minimum one)buyer

IV.from a (minimum one) ecosystem services provider

V.if and only if the ecosystem services provider secures ecosystem services provision (conditionality).

Wunder stated that when a scheme metall the 5 requirements, the case is a 'genuine PES'; but if only a few and not all 5 requirements are metthisis called a 'PES-like scheme' [15]. These criteria have been adopted in much of theliterature and are considered to be the mainstream concept of PES.

On the other hand, there exist several criticisms against this definition. Some researchers point out that since most of ecosystem services are public goods which require a high transactioncost, the voluntary transactionbetween buyer and seller cannotbe realized and the role of government might be significant in reality [16][17][18]. Wunder himself observes that the case which fulfils all the five requirements rarely exists [4]. He said the hardest criterion to meet is No.5 regarding conditionality, describing that many PES initiatives are loosely monitored and payments are made in good faith rather than being truly contingent on monitored service provision.

Considering the difficulty of fulfilling all requirements, in the following part of this article PES is used as a term which means a conservation schemewhich meets at least the first four criteria.

\section{Private Sector's Approach to PES}

\subsection{Research subjects}

\subsubsection{Two different PES types}

From the comprehensive survey of literatures including CSR reports of Japanese companies, it was revealed that there are scarce examples of PES in rural areas in Japan.

PES schemes implemented by the private sector may be grouped into two types according to the degree of directness of transaction between the two parties, buyer and seller. One type is that buyer companies and sellers, in most cases farmers or foresters, are indirectly connected through public institutions such as municipalities, in which companies pay for ecosystem service provision indirectly through the public institutions. Most cases fall into this category so this can be regarded as typical for PES by private companies in Japan. The other type is characterized by direct negotiation between companies and farmers/foresters. The relation between the companies and the farmers/foresters is closer than the former and the companies pay directly to farmers or foresters. Only a few available cases can be classified into this category, and such cases are quite rare in Japan. Due to the limitations of spacein this article, one representative example from each category is chosen and a more detailed analysis is undertaken. As for the former type of PES scheme, a case of a water source forest conservation project by a beverage company (in the following,referred to as company A) will be described. For the latter type of PES scheme, a ground water conservation project by a semiconductor manufacturing company (referred to as company B)is presented. In addition to the cases from Japanese companies, a waterquality protection project by French company Nestlé Water (referred to as Nestlé) is examined for comparison. 


\subsubsection{Methodology}

In this article comparative analysis is described to clarify the characteristics of the cases. For company A, the data was collected from open information on its website and by an interview with the person in charge of the conservation program.For company B, the data was collected mainly from open information in the websites of company $\mathrm{B}$ and an environmental NPO, the intermediary of the PES program later mentioned. Interviews were also conducted witha number of stakeholders, including the person in charge of the NPO and a person in charge of a Land Improvement District who were also intermediaries of the program.. As for the case of Nestlé, detailed information which is sufficient for analysis was acquired from the paper of Perrot-Maître Dand others [19].

\subsubsection{Motivation for Conservation of Water Resources}

Company A consumes around 10 million cubic meters of tap water per year (in 2012) in the process of beverage production. Needless to say, securing stable supply of water as a raw material is absolutely essential for the sustainability of their production activities. Nevertheless, the secondary forests which account for a larger part of the forests in Japan are in general deteriorated due to underuse, which may causea decline of forest hydrology. In response to this, the company started a forest conservation program in which it pays to those who manage the water conservation forests which are the source of water-supply for their factories, for example, local forestry cooperatives. Considering that in this program, company A pays to forest workers and managers through governmental schemes which are established to promote private companies' participation in forest conservation, this program can be regarded as indirect PES.

Company B began operations at its plant in a local area that is known to have rich groundwater, because of the necessity of acquiring large quantities of clean groundwater in the cleaning processes of the semiconductor plant. It uses around 2 million cubic meters of water per year (in 2012), including the groundwater and purchased industrial water. The groundwater source is located in the middle basin area of a neighbouring river. A research group made clear that the middle basin area has high water recharging capacity of 640 million square meters per year, which is 5 times or more than other areas. And the fact has also come out that the paddy fields in that area account for one-third of the recharging capacity, because the soil so easily lets water through. This means that the rich groundwater has (to some extent) been supplied by farmers who flood their agricultural fields. In recent years, however, it has come out that the groundwater level has lowered gradually because of reduced rice production and increasing urbanization [21].Reducing the risk of groundwater depletion was the important issue for company B because the groundwater is an essential resource for semiconductor production.So company B started the groundwater conservation program where itpays a fee to cover the management and preparation costs of volunteering local farmers who flood their fields with water drawn in from the neighbouring river when they aren't using the fields for agricultural production. Because in this PES program company B pays to farmers directly through a local Land Improvement District, it can be regarded as a type of direct negotiation.

Nestlé uses around 1.38 billion cubic meters of water per year (in 2012)[22]. Vittel mineral water which is one of the main products of Nestlé, originates in 'Grande Source' (means 'Great Spring'), located in the town of Vittel at the foot of the Vosges Mountains in north-eastern France. The water of Grande Source, which comes from a 6,0oo hectare aquifer 80 metres below ground level and is lifted naturally to the surface through a natural geological fault, has been well known since Gallo-Roman times and is reputed to cure kidney ailments. In the middle of the 1800 s the spring was purchased by Boulopumiéfamily and a spa developed in the town of Vittel, following which the reputation of the spring spread rapidly and people visited from all over Europe to drink its waters. The idea of bottling and marketing it developed in 1882 and the Société Générale des Eaux Minérales de Vittel (SGEMV) and the Vittel brand were created. By 1898 one million bottles had been sold. A century later one billion bottles are sold every year in 70 countries. In 1969, the Nestlé group purchased 30\% of the de la Motte family stock (then owners of the Vittel Brand), and in 1992 the spa and bottling plant was sold to Nestlé Inc. Then in 2002 the bottled water division subsequently became Nestlé Waters. Vittel is one of the ten top selling brands out of 75 brands marketed worldwide by Nestlé. AlthoughVittel water is labelled 'natural mineral water' with the most constraining legislation and high reputational risk andis characterised by a particularly low level of nitrates, the nitrate pollution risk was forecast to increase bythe research agency Agriculture-Environment-Vittel (AGREV)(which was established by Nestlé in partnership with a French research institute),because of the expansion of agriculture in the water catchment area.French legislation dictates that, if mineral concentration changes, the right to use the 'natural mineral water' label is lost. Preventing pollution and conserving water quality became a critically important issue for protecting the Vittel brand. Thereforein 1993 Nestlé started a conservation program by providing farmers in the water catchment area with economic incentives to voluntarily change their agricultural practices into more environment-friendly ways. In this program Nestlé pays farmers directly through an agricultural extension agency established byNestlé itself, so we can regard this PES program as a type of direct negotiation. 


\subsection{Indicators of comparison}

Five indicatorsare used for comparing the three cases. The first one is 'targeted ecosystem services and conservation activities'. 'Targeted ecosystem service' means the ecosystem servicesthatthe PES program is attempting to conserve and 'targeted conservation activities' meansthe activities paid for in the PES program. The second indicator is 'buyer and seller'. Here buyerrefers to those who benefitfrom ecosystem services and bear expenses for conservation of those services, whereas seller refers tothose who conserve and manage the ecosystem that provides the targeted ecosystem services andget compensation for their conservation activities. The third one is the 'intermediary', who mediates negotiation between buyer and seller. The fourth indicator is 'payment', which includes factors such as payment amount and form of payment. The fifth indicator is 'monitoring and evaluation', which is about whether the PES program has a monitoring or evaluationsystem or not.Theseindicators are largely extracted from the main components of PES programsdescribed by Wunder et al.[20]though some modification were made to suit the purpose of this article.

\subsection{Results of analysis}

The results of analysis are shown in Table1. Here we summarize the results.

\subsubsection{Targeted ecosystem services and conservation activities}

In all three cases investigatedin this article, a water service is targeted for conservation.First, in the case of company A, since thecompany continuously uses very large amountsof water for their beverage production, it pays for themanagementof the water conservation forests which are the source ofwater-supply for all of their 9 factories and 6 offices around the country. The conservation activities paid forare forest management, including thinning, forestry road management, weed clearing,planting and raising trees, and so on. The details of forest management works are decided according to the forest management plan established by the sellers, who are the foresters at the site, land owners and land managers. The buyer company allows the sellers to determine how the plan is carried out according to the

Table 1 Characteristics of private PES programs investigated

\begin{tabular}{|c|c|c|c|}
\hline $\begin{array}{l}\text { Indicators of } \\
\text { Comparison }\end{array}$ & Company A & Company B & Nestlé \\
\hline $\begin{array}{l}\text { Ecosystem } \\
\text { services and } \\
\text { conservatio } \\
n \text { acts }\end{array}$ & $\begin{array}{l}\text { Water } \\
\text { conservation } \\
\text { forest } \\
\text { management } \\
\text { aiming to } \\
\text { conserve tap } \\
\text { water }\end{array}$ & $\begin{array}{l}\text { Inundation of } \\
\text { paddy fields } \\
\text { aiming to } \\
\text { conserve } \\
\text { ground } \\
\text { water }\end{array}$ & $\begin{array}{l}\text { Conversion of } \\
\text { farming } \\
\text { methods } \\
\text { aiming to } \\
\text { conserve } \\
\text { water quality }\end{array}$ \\
\hline $\begin{array}{l}\text { Buyers and } \\
\text { sellers }\end{array}$ & $\begin{array}{l}\text { Payments to } \\
\text { forest owners' } \\
\text { cooperatives }\end{array}$ & $\begin{array}{l}\text { Payments to } \\
\text { farmers from } \\
\text { company B }\end{array}$ & $\begin{array}{l}\text { Payments to } \\
\text { farmers from } \\
\text { Nestlé }\end{array}$ \\
\hline
\end{tabular}

and citizens'

groups from

company A

Intermediarie Local

s governments

and public

organizations

of the country

Payments

N/A

Sending a few

thousands

weekend-

volunteers

per year

Evaluation No

and

No
quantitative

monitoring

system monitoring evaluation and

\begin{tabular}{|c|c|}
\hline $\begin{array}{l}\text { Local } \\
\text { environmental } \\
\text { NPO,a Land } \\
\text { Improvement } \\
\text { District }\end{array}$ & $\begin{array}{l}\text { Agricultural } \\
\text { extension } \\
\text { agency that is } \\
\text { trusted by } \\
\text { farmers }\end{array}$ \\
\hline $\begin{array}{l}11, \text { ooo yen per } \\
30 \text { days, } \\
16,500 \text { yen per } \\
60 \text { days and }\end{array}$ & $\begin{array}{l}200 \text { Euro for } \\
\text { income } \\
\text { compensation } \\
/ \text { ha }+15000\end{array}$ \\
\hline $\begin{array}{l}22, \text { ooo yen per } \\
90 \text { days (per } \\
\text { 10a) }\end{array}$ & $\begin{array}{l}\text { Euro for facility } \\
\text { investments }\end{array}$ \\
\hline $\begin{array}{l}\text { Periodic } \\
\text { evaluation and } \\
\text { monitoring of } \\
\text { recharging } \\
\text { volume }\end{array}$ & $\begin{array}{l}\text { Periodic } \\
\text { evaluation and } \\
\text { monitoring of } \\
\text { pollution } \\
\text { concentration }\end{array}$ \\
\hline
\end{tabular}

forest condition instead of planning or directing specific management works.In the second case, company B's PES program targets conservation of groundwater used for semiconductor production. The main controllable groundwater infiltration sources arethe paddy fields located in the middle basin area of a neighbouring river.Company Bhas concluded an agreement in which local farmers flood their agricultural fields in between crop cultivation periods, and in return, provides financial support for them.In the third case, the targetedecosystem service inNestlé's PES is water quality used for producing Vittel mineral water. In order to maintain aquifer water quality to its high standard, Nestlépays farmersto compensate the cost of reconverting to low impact dairy farming, including composting animal wastes, abandoning agrochemicals and so on, and to guarantee their income.

\subsubsection{Buyer and seller}

In all cases, buyers of the targeted ecosystem servicesare the companies who consume ecosystem services for their production activities. As for the seller, in the case of company A, it implements the PES program in 15 forest sites, which are the factories' or offices' water conservation forests. The total area of conserved forest is about 1,ooo hectares. Those who conduct conservation activities are forestry cooperatives, regional forest management offices, environmental Non-profitOrganizations (NPO) or others engaged in management ofthe water conservation forests.As for company B, sellers are the volunteer local farmers in two rural communities in the water catchment areawho conduct water flooding in their agricultural land in the off season between crop cultivation periods. Most of the farmers in the area have already participated in the program so far.In the case of Nestlé, sellers are the farmers who agree to change theirfarming practiceand technology to the targeted conservation activities mentioned previously. All 26 farms in the catchment had adopted the new farming methods by 2004 . 


\subsubsection{Intermediary}

In company A's approach, public institutions play an important role as intermediaries. For example, when a water source forest belongs toa national forest, the Forestry Agency or National Land Afforestation Promotion Organization select outsourced forestry workers and introduce them to the buyer company. As for the prefectural and municipal forest, the local governmentsmediatebetween the company andthe forestry worker. It is worthy to note thatwhen the company conductsthe program, it uses the governmental schemes to promote companies' participation in forest management,such as 'Hojin-no-Mori'by Forestry Agency and 'Kigyo-no-Mori' (both mean 'company' forest') by prefectural governments.

In the case of the company $\mathrm{B}$, a local environmental NPO and a Land Improvement District played a role as intermediaries. When the company began operations at its plant, the NPO sent an open letter concerning water consumption and pollution control in the plantand the company answered to it in an earnest manner. This led to a good relationship between the organisations. Latera suggestion was brought forth by the NPO to fully return the groundwater the company used. The suggestion was accepted and the company started the program. For this reason it can be said that the NPO triggered the PES program. The Land Improvement District, which is an agricultural water user organization, also played an essential role to find the farmers who voluntarily cooperate with the program.

As for Nestlés program, the negotiation with farmers was implemented under the leadership of Agrivair, an agricultural extension agencycreatedby Nestléin 1992. Although Agrivair is buyer-created and so is not a pure third-party organization, it has a solid local base and has been trusted by the farmers because the appointed director was formerly employed with a research team that worked on AGREV and is well-known among farmers and other stakeholders in the area. Furthermore, Agrivair was strategically located close to farmers andfarmers'associations so that it could contribute to ensure the participation of farmers in the design and implementation of the program and facilitate the communication of scientific information with them as well.

\subsubsection{Payment}

At company A, definite data regarding the amount of payments could not be obtained; however, the amount that was paid by the public institution (intermediary) was presented by the institution. This includes actual expenses on water conservation forest management and daily wages. In addition, employees are sent to help in maintaining water conservation forest as volunteers on the weekends and a few thousand employees are sent every year.

At company B, farmers are paida cooperation fee based on number of days and the area for filling water and the amounts are 11,000 yen per 30 days, 16,500 yen per 60 days and 22,00o yen per 90 days (all these values are per 1oha). These amounts were decided based on consultation with the Land Improvement District, the intermediary, and considering a series of expenses such as an actual expense and an administrative expense to fill water.They are decided as amounts to compensate part of those expenses.

At the Nestlé, the basic amount of the benefit for farmers was 200 Euro per 1 ha per year. This amount was decided as a result of negotiations with farmers that they can pay off their debts needed to purchase lands and also compensate their income during the contract period. Additionally, the company has compensated 15,00o Euro asa maximum amount to each farmer for expenses needed for things such as equipment for agricultural facilities accompanied with the change of farming method.

\subsubsection{Monitoring and evaluation}

At company A, as was already mentioned in 3.3.1, the details of management works of water conservation forests are decided by the sellers, who are the forest managers at each site. There is no scheme to monitor efforts by the managers or to quantitatively evaluate conservation effect.How much of the water resources are transacted in the PES program is not clear because the quantitative evaluation of the impacts and effectiveness of the forest managementon water cultivation hasnot been implemented.

At company B, periodic evaluation of ground water recharge quantity is conducted. In the evaluation scheme, company B aims to fully return the water into the ground whichits own factory used and it quantitatively evaluatesthe amount of groundwater recharged with help from the researchers at aneighbouring university.From 2003 to the 2011 fiscal year, the recharge volume successfullyexceeded the volume used by the factories in all 6 years except the 2005 fiscal year, and in the 2012 fiscal year, the amount of water recharged was 2.19 million cubic meters which is the same amount as the water consumed in that year.

At Nestlé, the research organization INRA and the mediator organization Agrivair, periodically monitor pollution concentration and guide farmers continuously. By 2004, after 12 years of operation, the PES program had succeeded in incorporating 92 percent of basin's hectares and reducing nitrogen load of the Spring's source water [23].

\subsection{The risk of ecosystem services loss influences designing of PES}

There were common points observed between company B and Nestlé,which are characterized bydirect negotiation and closer fit to the original form of PES.

The first point is that the conservation act of ecosystem services, which is the subject of payment, is specified. For company B, it is water filling by farmers and for Nestlé, change of agricultural methods to designated ones, both of which are limiting. On the other hand, for company A, detailed contents of the conservation act are left to the 
consignee of water conservation forest management, hence the company does not designate acts in detail.

The second point is that the quantitative monitoring and evaluation regarding enforcement of thescheme conditions and outcomes are conducted periodically. In the scheme of company $\mathrm{A}$, on the other hand, this is not enforced strictly.An important question is therefore, "How did these common points between the company B and Nestlé and the points of difference between those two companies and company A occur?"

By way of a reason for these, the background situation that both company B and Nestléhad in common is inferred to have an influence. As discussed in section 3.1.3, the fact that water services that are essential for their production activities have been exposed to the risk of shortages and pollution has been recognized, which is whycompany B and Nestlé started their schemes. That is, water services conservation was considered to be an urgent subject for both companies to continue their production activities. Therefore, it is presumed that the measures to reduce shortages and pollution were closely examined scientifically and they were indicated to farmers. It is presumed that both companies conducted quantitative monitoring and evaluation regarding scheme enforcement conditions and outcomes since obtaining the conservation effect was of absolute importance to them. In the case ofcompany A, itwas not under anurgent critical condition that their production activities were threatened. Considering that it doesn't have a scheme for quantitative evaluation of the program's effectiveness, it is assumed that not only water cultivation by forest conservation but some side objectives of the program, includingimproving employees' environmental awareness through volunteering activities and their interaction with local communities, arealso considered important. Actually, thousands of the employees and their family members participate voluntarily in the programeach year, helping forest conservation activities.

From these points, it can be considered that the state of ecosystem services utilized for companies' production activities being scientifically elucidated became an opportunity for more pure PES to be put into effect.

\subsection{The standard of setting payment amount varies depending on the objectives of the scheme and social situations}

On the other hand, the standard of setting the payment amount was observed to be a point of difference between company B and Nestlé.

At Nestlé, they have paid all the facility investment costs that can compensate farmers' income for participation in the PES, paying their debts and converting their farming methods to conservative ones, to prevent polluting actions by farmers completely. According to INRA's report, 11.3 million Euro has been paid for financial compensation to farmers and 3.81 million Euro to cover facility investment costs during the 7 years since the program started (INRA 1997). It can be said that they have thoroughly supported farmers to convert their farming methods to environmentally conservative farming methods to avoid losing the Vittel brand, their key commodity.

On the other hand, atcompany B, the amount that compensates a part of a series of expenses for farmers' water filling has been paid. An interesting answer to the question of why onlya part of expenses were covered and not the full amount, was obtained from the Land Improvement District,their intermediary. That is, if the amount of payment for water filling is set too high, there is a concernthat the farmers' being able to get high income from the scheme maylead to them losing the motivation for their agricultural activities, which is their principle occupation. In the PES by company $\mathrm{B}$, although ground water recharge is a direct objective, it should be enforced within an objective of local communities that farmers in the riverhead area independently continue their agricultural activities; hence, it was meant to support farmers continuing their agricultural activities by supporting forthe expenses required for water filling rather than compensating farmers' full income and make them dependent.

Thus, there are possibilities that the standard of setting payment amount varies depending on the objective of PES or the background of the society in which PES is enforced.

\subsection{The intermediaries may have various roles}

The intermediaries had an important role in the schemes of all three companies.

At company A, public organizations such as the local government select a location to conduct conservation activity and introduce the consignee for forest management, and by preparing various systems including "Kigyo-no-Mori", they provide an environment in which companies can comfortably work on their PES. Additionally, by public organizations' intervention, it can be presumed that understanding for the project can be more easily obtained as forest managers possess an awareness of, "Doing for public benefit". In the case ofcompany $\mathrm{B}$, a local environmental NPO made an opportunity for company B to start their PES. In addition, the Land Improvement District has undertaken setting up meetings with each farmer and information sessions to search for farmers who can cooperate on the project. It is considered that due to these actions, the negotiation expenses of company Bwere significantly reduced. In the case of Nestlé, Agrivair has undertaken setting up information sessions regarding the project for the farmers and also supporting farmers after the project has been enforced.

In this way, various actors can be intermediaries in PES. Moreover, intermediaries are considered to have a significant role as they facilitate communication between companies and farmers. 


\section{Conclusion}

The decline of agriculture and forestry has had negative impacts on sustainable use of the ecosystem services in rural areas. To arrest the loss of biodiversity and ecosystem services in the areas, continuous use and maintenance of forest and agricultural lands in a sustainable manner is necessary. PES is one of the potential tools which contribute to this challengebyremunerating positive externalities of ecosystem service provided by farmers and foresters.

Considering the equitableness in the cost burden, businesses, who are often one of the largest users of ecosystem services,are especially expected to bear the conservation costs for the sustainable management of forest and agricultural lands.Furthermore, they can possibly reduce the production risk by investing in ecosystem service conservation because ecosystem service degradation can pose various production risks, for example unstable raw materialsecurity. Therefore, ecosystem conservation is necessary for businesses to sustain their own production activities into the future.In other words, businesses'engagement in PES can possibly contribute not only to ecosystem service sustainability but also business sustainability.

Nevertheless, as the CBD-COP8 pointed out,the private sector is arguably the least engaged of all stakeholders in the implementation of the Convention (Decision VIII/17), and expanding private sector investment towards ecosystem conservation cannot be accomplished overnight. Some support systems are needed to promote their engagement.

What is important to promote PES by companies towards ecosystem service conservation in farming and mountain villages? First of all, it is considered important to make companies have a sense of benefitting-by the scheme and a sense of impending crisis, by making them aware of the condition of ecosystem services they utilize for the production activities. Scientifically elucidating the condition of ecosystem services in farming and mountain villages and the development of a database regarding it is fundamentally important. Next, it is important to examine a proper state of payment with a consideration of the social situation surrounding ecosystem services. The ecosystem services of Japanese farming and mountain villages should be supplied by continuous agricultural and forest management activities. In addition, since the PES with companies bearingall costs, like Nestlé, is considered to have low versatility, the level of PES payment which contributes to the independence of agriculture and forestry needs to be determined. It is expected that there must be sufficient opportunity to discuss the state of payment among stakeholders, including buyer companies, farmers, foresters, local people and so on.Finally, it is critical to strengthen intermediaries' roles to promote companies' introduction of PES and to facilitate its enforcement. It is necessary for public organizations, NPO's and research organizations to establish some system or institution in which companies can easily participate in PES.

\section{Acknowledgements}

Funding for this research was provided by Asahi Breweries Foundationuntil March 312012 . We would like toexpress our appreciation and thanks to all the intervieweesfor providing information on their program. Thank you also to Ms. Ria Adoracion Apostol Lambino for helpful comments on the draft.

\section{References}

[1] Annual Report on the Environment, the Sound Material-Cycle Society and the Biodiversity in Japan 2012. http://www.env.go.jp/en/wpaper/2012/index.html Accessed 1 April 2013.

[2] Japan Biodiversity Outlook: The Current State of Biodiversity in Japan,2010.

http://www.biodic.go.jp/biodiversity/shiraberu/policy/jbo/jbo/ files/Japan_Biodiversity_Outlook_EN.pdf Accessed 1 April 2013.

[3] WBCSD\&IUCN. Markets for Ecosystem Services: New challenges and opportunities for business and the environment. 2007

http://cmsdata.iucn.org/downloads/business_and_ecosystems_ september2007.pdf Accessed 1 April 2013.

[4] Wunder S. Payments for environmental services: some nuts and bolts. CIFOR Occasional paper; Bogor, Indonesia: Center for International Forestry Research;2005; No.42, 24pp

[5] EngelS, Pagiola S, Wunder S. Designing payments for environmental services in theory and practice : An overview of the issues. Ecological Economics 2008; No. 65; 663-674

[6] Brechin S, West P, HarmonD,Kutay K. Resident Peoples and Protected Areas : A Framework for Inquiry. In: West P and Brechin S, editors. Resident peoples and national parks : Social dilemmas and Strategies in international conservation, Washington, D.C., Island Press; 1991, p. 5 28

[7] Baland JM, Platteau JP. Halting Degradation of Natural Resources: Is There a Role for Rural Communities? Clarendon Press, Oxford; 1996

[8] NiestenE, Rice R. Sustainable Forest Management and Conservation Incentive Agreements. International Forestry Review 2004; 6(1); 56-60

[9] SwallowBM, Kallesoe MF, Iftikhar UA, Van Noordwijk M, Bracer C, Scherr SJ, Raju KV, Poats SV, Kumar DA, Ochieng BO,MalleeH, RumleyR. Compensation and rewards for environmental services in the developing world : framing pantropical analysis and comparison. Ecology and Society 2009; $14(2) ; 26$

[10] Hughes R, Flintan F. Integrating Conservation and Development Experiences: A Review And Bibliography of The ICDP Literature. Biodiversity and Livelihoods Issues, 2001. http://www.iied.org/pubs/pdfs/908oIIED.pdf Accessed 31 March 2013.

[11] Hardner], Rice R. Rethinking Green Consumerism. Scientific American 2002 May; p.89-95

[12] Ferraro PJ, Kiss A. Direct Payments to Conserve Biodiversity. Science 2002; No. 298; 1718-1719

[13] Rosa H, Kandel S,Dimas L. Compensation for environmental services and rural communities: lessons from the Americas. International Forestry Review 2004; 6(2); 187-194

[14] Pagiola S, ArcenasA, Platais G. Can Paymentsfor Environmental Services Help Reduce Poverty? An Exploration 
of the Issues and the Evidence to Date from Latin America. World Development 2005; 33(2); 237-253

[15] Wunder S. The efficiency of Payments for Environmental Services in Tropical Conservation. Conservation Biology 2006; 21(1); 48-58

[16] Sierra R, Russman E. On the efficiency of environmental service payments: A forest conservation assessment in the Osa Peninsula, Costa Rica. Ecological Economics 2006; No. 59; 131141

[17] Muradian R, Corbera E, Pascual U, Kosoy N, and May PH. Reconciling theory and practice : An alternative conceptual framework for understanding payments for environmental services. Ecological Economics 2010; No. 69; 1202-1208

[18] Vatn A. An institutional analysis of payments for environmental service. Ecological Economics 2010; No. 69; 1245-1252

[19] Perrot-Maître D. The Vittel payments for ecosystem services: a 'perfect' PES case? Project Paper 2006; No.3

[20]Wunder S. Engel S, Pagiola S. Taking Stock : A comparative analysis of Payments for Environmental Services Programs in Developed and Developing Countries.Ecological Economics 2008; No. 65; 834-852

[21] Kumamoto City. Kumamoto City Groundwater Conservation Plan: Establishment, Enhancement and Partnership, 2009. http://www.kumamotowaterlife.jp/base/upload/p48621_62_21p16391_39_21planhp.pdf Accessed onı April 2013.

[22] Nestlé Water. Creating Shared Value and meeting our commitments 2012: Full Report, 2012.http://www.nestle.com/asset-

library/documents/library/documents/corporate_social_respon sibility/nestle-csv-full-report-2012-en.pdf Accessed 16September 2013.

[23] United Nations Economic Commission for Europe. Payments for Forest - Related Ecosystem Services: What role for a Green Economy?

http://www.unece.org/fileadmin/DAM/timber/meetings/201107 04/o6o62011pes_background_paper.pdfAccessed 17 September 2013. 